\title{
UHRIN DOROTTYA
}

\section{Antiochiai Szent Margit legkorábbi magyarországi kultusza}

\author{
Álmos herceg egyházalapításai \\ és a Szent Margit-szakramentárium*
}

\begin{abstract}
Antiochiai Szent Margit - legendája szerint - a késő antik keresztényüldözések idején élt, fiatal keresztény lány volt. Egy nap szerelemre gyúlt iránta a pogány prefektus, Olibrius. Ám Margit megvallotta, hogy keresztény, s nem volt hajlandó feladni hitét és szüzességét a házasságért. Ennek következtében Olibrius börtönbe vetette, s borzalmasan megkínoztatta. Éjszaka a börtönben sem volt nyugta, mivel elöször egy sárkány jelent meg elötte (ami egyes verziók szerint el is akarta nyelni) majd az ördög ember formájában, ám Margit föléjük kerekedett. Olibrius belátva, hogy a kínzások nem törik meg a szüz hitét, lefejeztette. ${ }^{1}$

Izgalmas legendája s a neki tulajdonított jelentős közbenjárói szerep nyomán Szent Margit méltán vált a késő középkor egyik legnépszerübb női szentjévé mind Nyugat-Európában, mind Magyarországon. Jelen tanulmány mégis Antiochiai Szent Margit középkori magyarországi kultuszának a megjelenésével foglalkozik, illetve ezzel összefüggésben az Álmos herceg által alapított dömösi prépostság és meszesi apátság létrejöttére koncentrál. ${ }^{2}$ Erről a témáról a közelmúltban írt Orbán Imre, ${ }^{3}$ de nem tünik haszontalannak újra ráirányítani a figyelmet a problémakörre, a modern nyugati szakirodalom bevonásával. Emellett szükséges áttekinteni a herceg indítékait a dömösi és a meszesi Szent Margit egyházak alapítására.
\end{abstract}

\footnotetext{
* Az Emberi Erőforrások Minisztériuma Új Nemzeti Kiválóság Programjának támogatásával készült.

Itt szeretnék köszönetet mondani Thoroczkay Gábornak, Veszprémy Lászlónak és Zsoldos Attilának a tanulmány készítése közben nyújtott tanácsaikért.

${ }^{1}$ Szent Margit latin legendáinak a legnagyobb csoportja a BHL 5303, ez hatott leginkább a későbbi legendaváltozatokra. Bolland Johannes, Carnandet, Jean Baptiste, Henschenius, Godefridus (szerk.), Acta Sanctorum quotquot toto orbe coluntur, Antwerp-Brussels, 1643-1971, (a továbbiakban AASS), Jul. V., 33-39.

2 A dömösi királyi udvarházról és a prépostság alapításáról már számos munka született, így azt részleteiben (pl. a dukátus kérdése, a prépostság anyagi javakkal való ellátása stb.) nem tárgyalja a tanulmány. Legújabban Thoroczkay Gábor írt róla kutatástörténeti összefoglalót. Lásd THOROCZKAY Gábor, A dömösi prépostság története alapitásától I. Károly uralkodásának végéig = Fons, 19(2012), 409-433; ill. BENKö Elek, Udvarházak és kolostorok a pilisi királyi erdőben = Benkő Elek, Orosz Krisztina (szerk.), In medio regni Hungariae, Régészeti, müvészettörténeti és történeti kutatások „, az ország közepén.” Bp., MTA BTK Régészeti Intézet, 2015, 728-733.

3 Orbán Imre, ,,Ecce, iam vici mundum!” Antiochiai Szent Margit tisztelete Magyarországon, Bp., METEM, 2001 (METEM-könyvek, 32).
} 
Orbán Imre felvetette, hogy Álmos herceg a sárkányt legyőző Szent Margitot azért választotta a prépostság védelmezőjének, mert az alkalmatlan király elleni küzdelmet szimbolizálta, ${ }^{4}$ ezt a feltételezést szintén szükséges megvizsgálni.

\section{Szent Margit kultusza Magyarországon}

Álmos herceg kolostoralapitásai elött

Álmos herceg, Könyves Kálmán király öccse, két egyházat alapított Antiochiai Szent Margit tiszteletére: a dömösi prépostságot és a meszesi apátságot. Az alapítások pontos időpontjára nincsen adatunk, annyi bizonyos, hogy a Képes Krónika a herceg jeruzsálemi zarándokútja (1107-1108) után tárgyalja a dömösi egyház felszentelését. Orbán Imre véleménye szerint Margit már meglévő magyarországi kultuszának kiemelkedő állomása a két hercegi alapítás. ${ }^{5}$ Vizsgáljuk meg Szent Margit 11. századi hazai kultuszát!

A szakirodalom a névadást, az okleveles adatokat, a patrocíniumokat és a liturgikus könyvek szövegeit tekinti a 11 . századi kultusz nyomának. ${ }^{6}$

Elsőként a személynevekre tekintve máris negatív eredményt kapunk. A királyi család névadásában ugyanis nincsen biztos adatunk arról, hogy bármely hercegnőt Margitnak kereszteltek volna III. Béla leánya elött. ${ }^{7}$ A fennmaradt, - bár csekély számú - oklevélből úgy tünik, hogy a középkori magyarországi névadásban egyáltalán nem jelent meg a 12. század előtt a Margit név. Az első olyan Árpád-kori diploma, amelyben a névvel találkozunk, egy 1152. évi, királyi pecséttel ellátott magánoklevél, ${ }^{8}$ amelyet Margaretha úrnő adott ki. Azt nem tudjuk, hogy

${ }^{4}$ Orbán Imre, Miért éppen Margit? Álmos herceg kolostoralapitásáról = Aetas, 1997, 2-3, 42-50; ORBÁN 2001, i. m. 105-111.

5 Orbán 2001, i. m. 107-109.

${ }^{6}$ Orbán 2001, i. m. 107-110.

7 Korai magyar történeti lexikon, 9-14. század, föszerk. Kristó Gyula, Bp., Akadémiai Kiadó, 1994, Árpádok genealógiai táblázat. (A táblázat Kristó Gyula és Makk Ferenc munkája.) Vö. ZsolDos Attila, Az Árpádok és alattvalóik, Magyarország története 1301-ig, Debrecen, Csokonai Kiadó, 1997. Függelék, genealógiai táblázat. - III. Ince pápa 1208-as oklevele említést tesz II. András Margit nevü nagynénjéről, azonban nem tudni, hogy anyai vagy apai ágon voltak rokonok. Wertner Mór II. Géza király lányaként azonosította. WeRTNER Mór, Az Árpádok családi története, Nagy-Becskerek, 1892, 351. Illetve akár III. István lánya is lehetett. Margit személyéről bővebben lásd NeumANN Tibor, Egy morva „herceg” és egy Árpád-házi hercegnö leszármazottai (A Gyánúr-fiak eredete és rövid története) $=$ Acta Universitatis Szegediensis, Acta Historica 130, szerk. Makk Ferenc, Piti Ferenc, Szeged, 2009, 18-19.

${ }^{8}$ Az Árpád-házi királyok okleveleinek kritikai jegyzéke, Regesta regum stirpis Arpadianae critico diplomatica, I-II, Szentpétery Imre, Borsa Iván (szerk.), Bp., 1923-1987. (a továbbiakban RA) I. 82. sz., a kiadások felsorolásával - Az oklevél helyéről a 12. századi hazai oklevéladásban: Kumorovitz L. Bernát, A középkori magyar „magánjogi” irásbeliség első korszaka (XI-XII. század) = Századok, 97(1963), 11, és KuBINYI András, Királyi kancellária és udvari kápolna Ma- 
az úrnő magyar vagy külföldi származású volt-e, ahogy azt sem, hogy hány éves lehetett a végrendelkezéskor, de feltehetően a 12. században született.

Az oklevelekre térve a korai kultusz bizonyítékaként említik ${ }^{9}$ Szent László egy 1082. évi diplomáját. Az oklevél a veszprémi Szent Mihály templom birtokösszeírása, e szerint az egyház birtokának egyik határjele egy Szent Margit egyház mellett (iuxta basilicam sancte Margarethe) ${ }^{10}$ található. Azonban már a 19. században bebizonyosodott az oklevélrôl, hogy hamisítvány. ${ }^{11}$ Legújabban Karlinszky Balázs foglalkozott a datálásával: véleménye szerint a 14. században, feltételezhetően 1324 és 1327 között került sor az oklevél összeállítására. ${ }^{12}$ Az első hiteles adat Szent Margit veszprémi egyházára csak egy 1240 után keletkezett oklevélben található (ecclesie sancte Margarethe). A szakirodalom az oklevél datálására 1318-at javasol, ${ }^{13}$ ami alapján valószínü, hogy az egyház és a Szentmargitszege veszprémi városrész az Árpád-korból származik, de feltehetően annak a kései periódusából. ${ }^{14}$

A veszprémi mellett a Zala megyében fekvő hahóti monostort tartják még 11. századi alapítású Szent Margit egyháznak, de valójában leginkább a településről elnevezett kódex datálása (ld. alább) miatt tekintik Szent László-korinak a monostort. A fennmaradt adatok alapján a Hahót nemzetség valamely tagja alapította közelebbről nem ismert időpontban. Tóth Endre tanulmányában kimutatta, hogy a Hahót nemzetség Bajorországból (feltehetően Freising környékéről), származott, s onnan, vagy Karintiából érkezett az 1160-as évek környékén Magyarországra. ${ }^{15} \mathrm{Az}$ alapításról szóló oklevelekkel kapcsolatban sok kétely merül fel. Az 1234. évi alapítólevél ${ }^{16}$ egy 14. századi hamisítvány, amelyet a Hahótnemzetség azon ágához tartozó tagjai készítettek, akik egy 1356-os oklevél ta-

gyarországon a XII. század közepén = Levéltári Közlemények, 46(1975), 81; FeHÉRTór Katalin, Árpád-kori személynévtár (1000-1301), Bp., Akadémiai Kiadó, 2004, 516.

9 Orbán 2001, i. m. 106; Orbán 1997, i. m. 45.

${ }^{10}$ Diplomata Hungariae antiquissima accedunt epistolae et actae ad historiam Hungariae pertinentiam (ab anno 1000 usque ad annum 1196), szerk. I. Györffy Georgius, Budapestini, 1992, (a továbbiakban DHA) 81. sz.

${ }^{11}$ FeJÉRPataky László, A királyi kancellária az Árpádok korában, Bp., MTA, 1885, 12; PAULER Gyula, A magyar nemzet története az Árpádházi királyok alatt, I-II, Bp., MTA Könyvkiadó Vállalata, 1893, II, 756; RA I. 21. sz.

12 KaRlinszKy Balázs Péter, $A$ veszprémi káptalan a középkorban, A veszprémi székeskáptalan középkori birtokai, Piliscsaba, 2013, (doktori disszertáció) 23.

${ }^{13}$ Gutheil Jenő, Veszprém város okmánytára, 1002-1523, Veszprém, Veszprémi Érseki és Főkáptalani Levéltár, 2007, 17. sz.

${ }^{14}$ Gutheil Jenő, Az Árpád-kori Veszprém, Veszprém, Veszprém Megyei Levéltár, 1977, 183. Veszprém városrészeiről 1. Solymosi László, Veszprém korai történetének néhány kérdése = Válaszúton, Pogányság - kereszténység, Kelet - Nyugat. Konferencia a X-XI. század kérdéseiröl, szerk. Kredics László, Veszprém, 2000. május 8-10. Veszprém, MTA Veszprémi Területi Bizottsága, 2000, 129-157.

15 То́тн Endre, Hoholt - Hahót, A jövevény nemzetségek eredetéhez = Századok, 137(2003), 289.

${ }^{16}$ RA I. 536. sz. 
núsága szerint nem részesültek a monostor kegyuraságából. ${ }^{17}$ Vagyis nem az volt kétséges, hogy a monostor a Hahót-nemzetséghez kötődik, a vita arról szólt a 14. században, hogy melyik ág élvezheti a kegyuraságot. ${ }^{18}$ Bizonyos adatok azonban arra utalnak, hogy létezhetett egy kisebb egyház (ecclesia) Szent László korában is, ám ez feltehetően nem monostor (monasterium) volt. ${ }^{19}$ Valószínüleg a Szent Margitnak dedikált monostort a Hahót nemzetség alapította betelepülését - vagyis mindenképpen az 1160-as éveket - követően. Ha volt is 11. századi egyház Hahóton, védőszentje nem ismert. Szent Margittal való azonosításának egyetlen bizonyítéka az lenne, ha a Szent Margit-szakramentárium valóban itt keletkezett volna, ám a kódexet épp a feltételezett Szent Margit-egyház miatt lokalizálták a településre. A kódex hahóti használatára azonban nincs bizonyíték (1. alább). Sokkal valószínübbnek tủnik, hogy a Hahóti család ősei hozták magukkal Szent Margit kultuszát, s letelepedve ők alapítottak a tiszteletére monostort. ${ }^{20}$ A 11. századi Szent Margit-kultusz igazolására jószerével csak a liturgikus könyvek maradtak.

\section{A liturgikus könyvek}

Szent Margit korai magyarországi kultuszára utal ${ }^{21}$ a Szent Margit Sarcamentárium, ${ }^{22}$ amelyet gyakran említenek Hahóti kódexként is, feltételezett származási helyére utalva. Ebben a kódexben hangsúlyosan megjelenik Szent Margit kultusza. Emellett az úgynevezett Esztergomi benedikcionále ${ }^{23}$ említ egy Szent Margit egyházat. Ezen tanulmány elsőként a szakirodalmi álláspontokat mutatja be a kódexek keletkezési idejéről.

Az Esztergomi benedikcionálét és a Szent Margit-szakramentáriumot (vala-

17 RÁcz György, Pannonhalma és Ják, Egy királyi és egy magánkegyúri bencés monostor a középkorban = Mons Sacer, 996-1996, Pannonhalma 1000 éve, I-III, szerk. Takács Imre, Pannonhalma, Pannonhalmi apátság, 1996, I, 530.

18 Cselenkó Borbála, Szerzetesrendek az Árpád-kori Zala megyében, Zalaegerszeg, Zala Megyei Múzeumok Igazgatósága, 2006 (Zalai Kismonográfiák, 9), 38.

19 Erről bővebben 1. RÁcz 1996, i. m. 530; Cselenkó 2006, i. m. 39; VÁndor László, Archälogische Forschungen in den mittelalterlichen weltlichen und kirchlichen Zentren des Hahót-Buzád Geschlechts = Antaeus, 23(1996), 183-217; VALTER Ilona, Árpád-kori téglatemplomok a NyugatDunántúlon, Bp., METEM, 2005, 44.

${ }^{20}$ Szent Margit kultusza Nyugat-Európában a keresztes hadjáratokkal párhuzamban indult meg, mint a tanulmány későbbi részében részletesen bemutatásra kerül.

${ }^{21}$ Illetve Szent Margit ünnepe szerepel a Szelepcsényi-kódexben vagyis a Nyitrai Evangelistariumban. RADó Polikárp, Libri liturgici manuscripti bibliothecarum Hungariae, Budapestini, sumptibus Musaei Nationalis Hungarici, 1947 (Az Országos Széchényi Könyvtár kiadványai, 26), 179, Az Evangelistarium fakszimile kiadása: SopKo, Július, VALACH, Július, Nitriansky Kódex, Matica slovenská, 1987; RADÓ 1947, i. m. 176-177.

22 Zágráb, Knjižnica Metropolitana MR 126.

${ }^{23}$ Zágráb, Knjižnica Metropolitana MR 89. 
mint a Hartvik-agendát) ${ }^{24}$ gyakran kezelik együtt a kutatásban, mivel ezek azok a 11-12. század fordulójára datálható kódexek, amelyek ma a Zágrábi Érseki Könyvtárban találhatóak és a történeti kutatás szerint - Kniewald Károly véleményére támaszkodva -, a püspökség alapításakor kerülhettek oda. ${ }^{25}$

Paleográfiai vizsgálatok alapján az Esztergomi benedikcionálét ${ }^{26}$ és a Szent Margit-szakramentáriumot ${ }^{27}$ a 11 . század végére vagy a 12 . század elejére/első felére datálták a kutatók. Ám az Esztergomi benedikcionáléban nem szerepelnek az 1083-ban oltárra emelt magyarországi szentek, ezért a kódexet jellemzően a 11. századra keltezték. Viszont a kutatók joggal utaltak rá, hogy talán némi késéssel jelentek meg a liturgiában az új szentek, így terminus ante quem-ként az 1092. évi szabolcsi zsinat időpontját ${ }^{28}$ vagy 1100 -at mint az I. esztergomi zsinat időpontját adták meg. ${ }^{29}$

${ }^{24}$ Zágráb, Knjižnica Metropolitana MR 165. Erről újabban 1. FöldVÁRY Miklós István, Egy úzus születése A Chartvirgus-ponrifikálé és a magyarországi liturgia megalkotása a XI. században, Bp., Argumentum, 2017. (megjelenés alatt) http://vallastudomany.elte.hu/sites/default/files/Publika\%CC $\% 81$ cio $\%$ CC $\% 81 \mathrm{k} / \mathrm{FMI} / \mathrm{Egy} \% 20 \mathrm{u} \% \mathrm{CC} \% 81$ zus $\% 20$ szu $\% \mathrm{CC} \% 881$ ete $\% \mathrm{CC} \% 81$ se_2014_01_24. pdf (2016. 10. 11.); Somogy Szilvia, A Hartvik-agenda és a kánonjog = Micae Mediaevales, Tanulmányok a középkori Magyarországról és Európáról, I, szerk. Kádár Zsófia, Mikó Gábor, Péterfi Bence, Vadas András, Bp., ELTE BTK Történettudományok Doktori Iskola, 2011, 121-132.

${ }^{25}$ KnIEwald Károly, A „Hahóti kódex” (Zágrábi MR 126. kézirat) jelentősége a magyarországi liturgia szempontjából = Magyar Könyvszemle, 62(1938/2), 100; KNIEWALd Károly, Az Esztergomi Benedictionale (XI. század) = Magyar Könyvszemle, 65(1941/3), 213.

${ }^{26}$ Az Esztergomi benedikcionálét Germain Morin a 11-12. századra datálta. Lásd MoRIN, Germain, Manuscrits Liturgiques Hongrois des XIe et. XIIe Siècles = Jahrbuch für Liturgiewissenschaft VI, 1926, 60-63. - Kniewald 1075 és 1100 közötti időpontot tartott lehetségesnek 1. KNIEWALD 1941, i. m. 227-228. - Veszprémy szerint a benedikcionále 11. századi írású. L. VeszPRÉMY László, A 12. századi magyar kódexírás kialakulása = Századok, 132(1998), 226; FöldVÁRY Miklós István, Az Esztergomi benedikcionále. Irodalom és liturgia az államalapítás-kori Magyarországon, Bp., Argumentum, ELTE BTK Vallástudományi Központ Liturgiatörténeti Kutatócsoport, 2014, 26-30.

27 A Szent Margit-szakramentáriumról 1. VIDAKović, Albe, Sakramentar MR 126 metropolitanske knjižnice u Zagrebu, Jugoslavenska Akademija Znanosti i Umjetnosti, Zagreb, 1952, 57-58; VESZPRÉMY László, Legkorábbi hazai sacramantáriumaink = Tanulmányok a középkori magyar könyvkultúráról, Szelestei N. László, Bp., OSZK, 1989, 125-126, (a továbbiakban VeSZPRÉMY 1989a); VESZPRÉMY 1998, i. m. 226.

${ }^{28}$ KNIEWAld 1941, i. m. 227; SzEndrei Janka, A „,mos patriae” kialakulása 1341 elötti hangjegyes forrásaink tükrében, Bp., Balassi, 2005, 55-58. - A zsinat 38. kánonjáról van szó: ZÁvodszKY Levente, A Szent István, Szent László és Kálmán korabeli törvények és zsinati határozatok forrásai (Függelék: a törvények szövege.), Bp., Szent István-Társulat, 1904, 164; újabb kiadása: BAK, János M., BónIs, György, SweEney, James Ross, Decreta Regni Mediaevalis Hungariae - The Laws of the Medieval Kingdom of Hungary, I. 1000-1301, (The Laws of Hungary. Series I. 1000-1526.) Idyllwild CA, 1999, I. 58. (a továbbiakban DRMH I.) - Magyar fordítás: Írott források az 1050-1116 közötti magyar történelemröl, szerk. Makk Ferenc, Thoroczkay Gábor, Szeged, JATE Középkortörténeti Tanszék, 2006 (Szegedi Középkortörténeti Könyvtár, 22) 158. (a továbbiakban ÍF)

${ }^{29}$ KNiewald 1941, i. m. 228, Szendrei 2005, i. m. 47, FöldvÁry 2014, i. m. 28. A zsinat szövege: ZÁvodszKY 1904, i. m. 200; DRMH I. 61, 126. - Magyar fordítás: ÍF 225. 
A Szent Margit-szakramentáriumban szerepelnek az új szentek ünnepei, tehát 1083 után keletkezett. Ám mivel a szakramentáriumot az Esztergomi benedikcionáléval egyetemben a Zágrábi Érseki Könyvtárban őrzik, ezért Szent László legendáját mértékadónak tekintve - amely szerint a király bőségesen megadományozta az újonnan alapított zágrábi püspökséget - és ezekre a kódexekre vonatkoztatva, úgy vélik, hogy a zágrábi püspökség alapítása ${ }^{30}$ utáni években, de 1096tal bezárólag kerülhetett a benedikcionále és a szakramentárium Zágrábba. ${ }^{31}$

A datálással kapcsolatban azonban számos probléma merül fel:

Az 1083-ban szentté avatottak hiánya az egyik érv a benedikcionále 11. századi datálásához. Kérdés azonban, hogy biztosan automatikusan kerültek-e bele az új szentek minden 1083 után közvetlenül készült liturgikus könyvbe? Szendrei Janka szerint nem kell ragaszkodni szorosan az 1083-as évhez mint határhoz, hiszen csak 1092-ben rendelte el a szabolcsi zsinat ezen szentek tiszteletét. ${ }^{32}$ Legújabban Földváry Miklós foglalkozott az Esztergomi benedikcionáléval, az ő véleménye szerint sem perdöntő a datálásban a magyarországi szentek hiánya, mivel még a 13. század elejéről is tudomásunk van olyan, minden bizonnyal magyarországi eredetü liturgikus könyvröl, amelybe nem kerültek bele ezek a szentek. Sőt az Esztergomi benedikcionále 14. századi kiegészítésekor sem pótolták az első hazai szentek neveit a litániában. ${ }^{33}$ Szendrei szerint - Kniewald véleményét elfogadva - a zágrábi püspökség alapításakor küldték a kódexeket Zágrábba, így terminus ante quem-ként az 1093-as évet adta meg, de elképzelhetőnek tartott néhány év késlekedést is. ${ }^{34}$ Földváry - szintén Kniewaldra alapozva - a benedikcionále elkészülte idejének felső határát az I. esztergomi zsinathoz kötötte és 1100-ban szabta meg. „Ekkor ugyanis az esztergomi zsinat mértékadónak nyilvánított egy bizonyos liturgikus tárgyú libellus-t: ezt sokan Konstanzi Bernold Micrologus-ával azonosítják, a Micrologus pedig helyteleníti a Szentháromság ünnepét, amely viszont az S [Esztergomi benedikcionále - kieg. UD.] áldásgyüjteményének szerves része." 35 Az I. esztergomi zsinat időpontját azonban minden bizonnyal egy tévedés miatt datálták a szakirodalomban 1100 -ra. ${ }^{36} \mathrm{~A}$ zsinati határozatok - a fennmaradt kézirataik alapján - 1104/05 (Lőrinc érseki székbe lépése)

${ }^{30}$ Legújabban Körmendi Tamás az 1089-1090 közötti alapítás mellett érvel. L. KöRMENDI Tamás, A zágrábi püspökség alapitási éve = „Köztes-Európa” vonzásában. Ünnepi tanulmányok Font Márta tiszteletére, szerk. Bagi Dániel, Fedeles Tamás, Kiss Gergely, Pécs, Kronosz, 2012, 340.

31 A „Hahóti”-kódex Kniewald Károly véleménye szerint 1073-1093 között készült, szerinte a zágrábi püspökség alapításáig meg kellett érkeznie a mostani tartózkodási helyére, mivel Szent László legendája szerint bőségesen ellátta javakkal az új püspökséget KNIEWALD 1938, i. m. 110. Ezt átvette a későbbi szakirodalom.

32 SZENDREI 2005, i. m. 47.

33 FöldVÁRY 2014, i. m. 27.

34 SZENDREI 2005, i. m. 47. 34. lj.

35 FÖLdVÁRY 2014, i. m. 9.

${ }^{36}$ Miкó Gábor, $A$, szent királyok törvényei”. A kora Árpád-kori törvények fennmaradásának története $=$ Századok, 150(2016), 326, 29. lj. 
után keletkeztek. ${ }^{37}$ A kérdésről az utóbbi évtizedekben bővebben Jánosi Monika írt, aki a zsinat időpontjának felső határául az 1112-1113-as évet adta meg. ${ }^{38}$ Thoroczkay Gábor véleménye szerint a zsinat inkább Lőrinc érsekségének első éveiben történhetett. ${ }^{39}$

„Két püspökséget szervezett, s királyi bőkezüséggel berendezett." ${ }^{40}$ - Szent László legendájának eme passzusát szokták a három zágrábi liturgikus könyvre értelmezni. Azonban nem szabad elfelejteni, hogy a legendák célja olyan képet festeni az adott szentről, ami alapján érdemes a szentségre. László bizonyosan ellátta anyagi javakkal a püspökséget, erről egy oklevél is tájékoztat. Az 1134-ben kiadott diploma szerint „Amikor a legnemesebb László király uralkodott, [...] az előbb említett király az isteni kegyelemtől indíttatva ezeknek és más nemeseknek a tanácsára megalapította a zágrábi püspökséget, [...] Azonkívül másik káplánja: név szerint Koppány ugyanezen király parancsára ugyanennek az egyháznak Dombróból adott népet földdel és a hozzá tartozó erdővel." ${ }^{41}$ Tehát az oklevél csak arról számol be, hogy Szent László birtokot adományozott a püspökségnek. A szabolcsi zsinat - akárcsak korábban Szent István törvénye ${ }^{42}$ - az elpusztult egyházakról szóló passzusában úgy rendelkezik, hogy kelyhet és ruhákat a király költségén vegyenek, könyvekről pedig a püspök gondoskodjék. ${ }^{43}$ Minden bizonnyal szüksége volt a püspökségnek szerkönyvekre, azonban a megalapítását követő első évtizedekben is támogatásra szorult. Egyáltalán nem biztos, hogy László uralkodásának utolsó évéhez kell kötni a kódexek megérkezését, ahogyan az sem bizonyítható, hogy a László idején érkezett kéziratok fennmaradtak.

Visszatérve Szent Margit kultuszára, úgy tünik, hogy Álmos herceg alapításai előtt - a bizonytalan datálású liturgikus kódexeket nem számítva -, csupán negatív eredményünk van a kultusz létezésével kapcsolatban. Szendrei Janka szerint az Esztergomi benedikcionále datálását ,a Szent Margit monostor biztos azonosítását elérő kutatás vinné előbbre". ${ }^{4}$ IIgy térjünk rá a Szent Margitszakramentárium keletkezési helyének a kérdésére, hiszen az szinte bizonyosan egy, a 11-12. század fordulóján vagy a 12. század elején már fennálló Szent Margit egyházban keletkezett.

${ }^{37}$ Az esztergomi zsinat irodalmáról lásd Uo.; THOROCZKAY Gábor, Megjegyzések a Hartvik-féle Szent István legenda datálásának kérdéséhez = THoroczKAY Gábor, Írások az Árpád-korról, Történeti és historiográfiai tanulmányok, Bp., L'Harmattan, 2009 (TDI Könyvek, 9), 73.

38 Jánosi Monika, Az első ún. esztergomi zsinati határozatok keletkezésének problémái = Acta Universitatis Szegediensis. Acta Historica, 83(1986), 23-30.

39 THoroczKay 2009, i. m. 73.

40 Szent László király legendája = Árpád-kori legendák és intelmek, Szentek a magyar középkorból, I, szerk. Érszegi Géza, Bp., Osiris, 2004, 91-92.

${ }^{41}$ DHA I. 261. - Magyar fordítása ÍF 319-320. Az oklevélről legújabban 1. KöRMENDI 2012, i. m.

42 ZÁvodszKY 1904, i. m. 153; DRMH I. 9.

${ }^{43}$ A 7. cikkelyében. ZÁvodszky 1904, i. m. 159; DRMH I. 57. - Magyar fordítás: ÍF 150.

44 SzendRei 2005, i. m. 47, 34. $1 \mathrm{j}$. 


\section{A Szent Margit-szakramentárium}

A Szent Margit-szakramentárium a legkorábbról fennmaradt magyarországi szakramentárium. A kódexet jelenleg az Zágrábi Érseki Könyvtárban ôrzik. Noha készült róla kutatástörténeti összefoglalás ${ }^{45}$ a leglényegesebb információkat mégis fontos összefoglalni. A kódex 111 fólióból áll, a felépítése csonka temporále (hamvazószerdától a pünkösd utáni 26. vasárnapig), egész éves szanktorále, szentek kommúne miséi, votívmisék és áldások ${ }^{46} \mathrm{~A}$ szakramentárium magyarországi eredete - a benne szereplő magyar vonatkozású szentek miatt - és bencés kötődése kétségtelen, ${ }^{47}$ mivel az in monasterio pro fratribus votívmise kollektája így szól: ,,Concede nobis famulis tuis in hoc presenti monasterio sancte Margarete uirginis nec non sub regula sancti Benedicti constitutis...". Tehát a kódex egy bencés regulát követő Szent Margit-egyház számára készült, s később kerülhetett Zágrábba. ${ }^{48}$

Paleográfiai szempontokat figyelembe véve a kutatók a 11-12. század fordulója és a 12. század közepe közé datálták. ${ }^{49} \mathrm{~A}$ kódex keletkezési helyéül több lehetőség is felmerült: Kniewald Károly Hahótot tartotta a lehetséges helyszínnek, Erdélyi László felvette Garábot (Szerém vármegye) ${ }^{50}$ illetve Béla (Pozsega vármegye) is felmerültt, ${ }^{51}$ ezeket később elvetették az egyházak kései említése miatt (a hahóti származást is, ám ez az elmélet a legelterjedtebb).$^{52}$ Olyan vélemény is létezik, hogy a Szent Margit-patrocíniumot külföldön kell keresni, s a kódex egy külföldi példány másolata, ${ }^{53}$ ezt a véleményt viszont szintén elutasította a szakma. ${ }^{54}$ Peter Ratkoš szerint a szakramentáriumban hangsúlyos Zoerárd-András és Benedek, Zobor-hegyi remeték kultusza, s ez nyitrai kapcsolatot feltételez, illetve

45 Uo. 55-65.

${ }^{46}$ KNIEWAld 1938, i. m. 102-106.

47 Uo. 55.

${ }^{48}$ KNIEWALD 1938, i. m. 98.

${ }^{49}$ Vidaković 1952, i. m. 57-58; Veszrrémy 1989a, i. m. 125-126; Veszzrémy László, Szentkultusz a korai liturgikus kódexeinkben = Ars Hungarica, 17(1989), 19 (a továbbiakban VesZPRÉMY 1989b); Veszrrémy László, A 12. századi magyar kódexírás kialakulása = Századok, 132(1998), 226; SZENDREI 2005, i. m. 56.

${ }^{50}$ ERdÉLYi László, $A$ „Hahóti Kódex” jelentősége a magyarországi liturgia szempontjából (recenzió) = Pannonhalmi Szemle, 1938, 303.

${ }^{51}$ Germain Morin vetette fel. Idézi KNIEWALD 1941, i. m. 219.

52 VeszPrÉmy 1989a, i. m. 123.

53 FANCEV, Fránjo, Liturgijsko-obredne igre u zagrebačkoj stolnoj crkvi, Narodna Starina I. Zagrab, 1925, 1-16.

${ }^{54}$ Már Kniewald úgy vélte, hogy Fancev ,eleve hajlamos arra, hogy a horvát liturgia forrásait és mintáit, ha magában Horvátországban nem találhatók meg, Csehországban keresse" KNIEwALD 1941, i. m. 216. 
felhívta a figyelmet arra, hogy világi papok számára készült szertartások is találhatóak a kódexben. ${ }^{55}$

Részben Ratkoš eredményeit továbbgondolva Veszprémy László arra a következtetésre jutott, hogy a dömösi Szent Margit társaskáptalan tagjai számára íródhatott a szakramentárium. ${ }^{56} \mathrm{~A}$ dömösi származás lehetőségét már Radó Polikárp is felvetette az Esztergomi benedikcionále és a Szent Margit-szakramentárium kapcsolatainak vizsgálata nyomán. A benedikcionále említ egy, az esztergomi egyházmegye fennhatósága alatt álló Szent Margit egyházat, amely Radó Polikárp számára egyértelmúen a dömösi társaskáptalan volt. ${ }^{57} \mathrm{~A}$ benedikcionále felsorolja azon egyházakat, amelyek klerikusai a szentelésüket Esztergomból nyerték, ebben szerepel egy Szent Margit-egyház (de monasterio S. Margarete). A monasterium megnevezés nem zárja ki a dömösi társaskáptalant a lehetséges Margit-egyházak közül, - sőt a Képes Krónika is a monasterium szót használja a dömösi egyházra, - mivel a korai magyar történelemben a monasterium szót a káptalanok megnevezésére is használták. ${ }^{58} \mathrm{Ha}$ a Dömössel való azonosítást elfogadjuk, - Veszprémy szerint - az Esztergomi benedikcionálét sem lehet 1083 elé datálni, annak ellenére, hogy nem szerepelnek benne az 1083-ban kanonizált magyarországi szentek. ${ }^{59} \mathrm{~A}$ benedikctionále bejegyzését a dömösi társaskáptalannal azért is logikus azonosítani, mivel - bár a 11. századi magyarországi forrásaink jelentős része nem maradt fenn - a felsorolásban említett egyházak (esztergomi székesegyház, székesfehérvári társaskáptalan, óbudai társaskáptalan, zoborhegyi bencés perjelség, garamszentbenedeki bencés apátság ${ }^{60}{ }^{60} 1$ ismertek mind a mai napig. Igy nehezen feltételezhető, hogy teljesen feledésbe merült az említett Szent Margit-monasterium. Veszprémy Dömös társaskáptalani jellegét a szakramentárium bencés jellegzetességeivel úgy egyeztette össze, hogy szerinte a dömösi káptalan tagjai kezdetben bencés regula szerint éltek, s számukra készült a szakramentárium a 12. század elején, majd innen került később Zágrábba. ${ }^{61}$ Thoroczkay Gábor véleménye szerint viszont kérdéses a bencés regula használata egy világi társaskáptalan esetében. ${ }^{62} \mathrm{~A}$ kódex történetéből az tünik ki, hogy föként világi papi használatban volt, legalábbis a 14. századtól, mikor már bizonyíthatóan a zágrábi káptalan őrizetében és használatában volt. ${ }^{63}$ Ha pedig tényleg a zágrábi püspökség alapítása utáni időszakban került oda, akkor az is

\footnotetext{
55 Ratкoš, Peter, Vznik kultu Ondreja-Svorada a Benedikta vo svetle zagrebskyoh pamiatok = Historijski zbornik (Sidakov zbomík), 1976-1977, 77-86.

${ }^{56}$ VeSZPRÉMY 1989a, i. m. 121-135.

${ }^{57}$ RAdó Polikárp, A magyar liturgia eredete a XI. században = Vigília, 1957, 393-394.

58 THOROCZKAY 2012, i. m. 411-412.

59 VesZPRÉmy 1989a, i. m. 129.

${ }^{60}$ Földváry 2014, i. m. 27, és Szendrei 2005, i. m. 48.

${ }^{61}$ Veszrpémy 1989a, i. m. 121-135.

62 ThoroczKay 2012, i. m. 414.

${ }^{63}$ Veszrémy 1989a, i. m. 128.
} 
kérdéses, hogy valaha használták-e bencés kolostori környezetben (attól függetlenül, hogy eredetileg arra szánhatták).

Érdemes azt is figyelembe venni, hogy van egy másik olyan kódex, amelyben a világi papság és a szerzetesség számára készült szertartások keverednek: ez az egy évszázaddal későbbi Pray-kódex (1192-1196) ${ }^{64}$ Emellett van még egy jelentős hasonlóság a Pray-kódex és a Szent Margit-szakramentárium között: mindkét kódexben kiemelkednek a magyar uralkodóház szentjeinek ünnepei. A szakramentárium említi elsőként Szent Imrét és Szent Istvánt liturgikus keretek között. ${ }^{65}$ Noha Szent István liturgikus tételei mindig jelen voltak, ${ }^{66}$ a Szent Margit-szakramentárium és a Pray-kódex megemlékezései az uralkodó család szentjeiről kiemelkedő intenzitásúak. ${ }^{67}$ A Pray-kódexről pedig azt feltételezi a legújabb szakirodalom, hogy erősen kötődött a királyi udvarhoz. ${ }^{68}$

Klaniczay Gábor bemutatta, hogy Magyarországon 1083 elött legfeljebb igen szerény kultusza lehetett Istvánnak, Imrének és Gellértnek. A László-féle kanonizáció egy átgondolt, merőben újító vállalkozás volt, amellyel megteremtett egy új szenttípust. István, Imre és Gellért kanonizációjának politikai funkciói is voltak. ${ }^{69}$ Szent László a szentté avatások után nem sokkal, 1092-ben a szabolcsi zsinaton rendelkezett István, Imre és Gellért ünnepének a kötelezővé tételéről (viszont Zoerárd-Andráséról és Benedekéről nem) ${ }^{70}$ vagyis nem gyökerezett meg olyan hamar a tiszteletük Magyarországon. Kálmán király uralkodása alatt egyik fontos feladatának tekintette, hogy elismertesse Szent István kultuszát a pápáknál, akik a fennmaradt leveleikben Istvánra még nem szentként utaltak. ${ }^{71}$ Az uralkodó által bevezetett új szenttípus, új szentkultusz vajon mennyi idő alatt terjedt el az országban? István, Imre és Gellért szentsége minden bizonnyal az uralkodói családnak volt a legfontosabb, ők voltak a kultusz legfőbb előmozdítói.

A Szent Margit-szakramentárium szanktorále részében István, Imre és Gellért ünnepe nem szerepel, viszont Zoerárd-Andrásé és Benedeké igen, így valószínü-

${ }^{64}$ Leírása: BARTONIEK, Emma, Codices manu scripti Latini. I. Codices Latini medii aevi, Budapestini, 1940 (A Magyar Nemzeti Múzeum Országos Széchényi Könyvtárának címjegyzéke, 12), I, 1-5.

${ }^{65}$ Tӧвӧк József, Szent Imre liturgikus tisztelete a középkorban = Szent Imre 1000 éve. Tanulmányok Szent Imre tiszteletére születésének ezredik évfordulója alkalmából, szerk. Kerny Terézia, Székesfehérvár, 2007, 47-49; Тӧвӧк József, Szent István tisztelete a középkori magyar liturgiában = Szent István és kora, szerk. Glatz Ferenc, Kardos József, Bp., MTA Történettudományi Intézete, 1988, 198.

${ }^{66}$ SzEndRei 2005, i. m. 127.

${ }^{67}$ Lásd Török József említett tanulmányait.

${ }^{68}$ SzEndRei 2005, i. m. 160; HoRvÁth Iván, Ómagyar szövegemlékek mint textológiai tárgyak, Bp., OSZK, 2015, 109, 117.

${ }^{69}$ KlanicZAY Gábor, Az uralkodók szentsége a középkorban, Magyar és európai dinasztikus szentkultuszok a középkorban, Bp., Balassi, 2000, 114-120.

${ }^{70}$ ZÁvodszKY 1904, i. m. 163-164; DRMH 60. - Magyar fordítás: ÍF 158-159.

71 ThoroczKay 2009, i. m. 76; Gerics József, Szent László uralmának vitás kérdései a legendában és a krónikában = Aetas, 1994, 1, 30. 
leg a szanktorále 1083 előtti. ${ }^{72}$ Veszprémy László vizsgálta meg a szanktorálét abból a szempontból, hogy melyek azok a regionálisan tisztelt szentek, akiknek ünnepei megtalálhatóak benne, amelyek korábban talán ismeretlenek voltak Magyarországon. Vagyis ezzel a szakramentárium alapját képező kéziratok (talán több másolatot megelőző) feltételezett tartalmát kötötte helyhez vagy régióhoz. A Szent Margit-szakramentárium szanktoráléja, Szent Audonius és Szent Wandregilis roueni püspökök és Sámson doli püspök ünnepei alapján a roueni egyháztartományra utal. Vagyis a szanktorále egyik rétege a Karoling birodalom nyugati részéről származó kódexből eredhetett. ${ }^{73}$ Szent Margit korai kultuszára tekintve azt állapíthatjuk meg, hogy a nyugat-európai liturgikus források alapján a 8-11. század között a vértanú szüz kultusza nem volt kiterjedt, leginkább a Köln és Tours környéki régiókra korlátozódott. A Francia Királyság középső és északi részén a 11. század előtt nem említették Margit ünnepét, ${ }^{74}$ vagyis a nyugat-francia területekhez köthetjük, akár a püspök szenteket.

A szakramentárium nagyszombati litániájában Szent István, Szent Imre és Zoerárd-András neve szerepel, ami azért különös, mivel a nagyszombati litániában ezt követően nem említik a zobor-hegyi remetét. Szendrei Janka szerint Zoerárd-András szerepeltetése nem magyarázható a kódex összeállítójának a bencés öntudatával (a szintén bencés Gellért nem bukkan fel benne). Viszont Kálmán idején a nyitrai püspökség megalapítása a zobori-hegyi remeték kultuszának egy második felfutását hozta el. Zoerárd-András kultuszának a hangsúlyozásában része lehetett a személyes (uralkodói) devóciónak is, hiszen I. Géza a dukátus uraként megszerezte András cilíciumának a felét ereklyeként, ${ }^{75}$ fiainak, Kálmánnak és Álmosnak is fontos lehetett a zobor-hegyi remete kultusza.

A Szent Margit-szakramentárium fogadalmi miséi között helyi vonatkozású, aktuális anyagok találhatók: megemlékezés Szent Ilonáról, Szent Györgyről, Szent Adalbertről, Szent Gellértről, Szent Egyedről, Szent István királyról, Szent Imréről, és ezután pedig Szent Margit könyörgések olvashatók. ${ }^{76}$ Ebbe, az aktualitásokat feldolgozó függelékes részbe a bencés elődök és Szent Margit közé „beékelték” a dinasztikus magyar szentek ünnepeit, ami a királyi családdal való kapcsolatra utalhat. ${ }^{77}$

A fentebb elmondottak alapján a Szent Margit-szakramentárium rendeltetési helyéül egy olyan Szent Margit-egyházat érdemes keresni, ahol kiemelkedően fontos volt a dinasztia szent ősei kultuszának ápolása, s élt a Zoerárd-András

72 VeszPrémy 1989a, i. m. 126.

73 VeszPrémy 1989b, i. m. 16-19. - Ezzel megerősíti Kniewald feltételezését. Lásd KNIEWALD 1938, i. m. 102-104.

${ }^{74}$ Dresvina, Juliana, A Maid with a Dragon. The Cult of St Margaret of Antioch in Medieval England, Handbook with Texts, Oxford, Oxford University Press, 2016, 20.

75 SZENDREI 2005, i. m. 58-59.

76 MR 126 f. 80-83v.

77 То́тн Sándor, Román kori kőfaragványok a Magyar Nemzeti Galéria Régi Magyar Gyüjteményében, Bp., 2010 (A Magyar Nemzeti Galéria Szakkatalógusai, I/1), 66. 
tisztelete is. Ezeknek a feltételek együtt leginkább az Álmos herceg által alapított egyházak felelnek meg. Miként a fentebbiekből kiderült a legkorábbi Szent Margitnak dedikált egyházak Álmos herceg alapításai, ezért feltételezésünk szerint ő honosította meg a vértanú szüz kultuszát, s a kódexet Álmos herceg környezetéhez tartozó bencések számára készítették.

\section{Dömös és Meszes alapitása}

A meszesi bencés apátság ${ }^{78}$ alapítási körülményeinek a feltárásához nincsenek segítségünkre a források. A legkorábbi adat a monostorról II. Géza 1152. évi (ismeretlen tartalmú) oklevele, amely megerősíti javaiban, ${ }^{79}$ III. István 1165 . évi okleveléből ${ }^{80}$ pedig arról értesülünk, hogy a király saját és apja lelki üdvéért az Álmos herceg által alapított meszesi monostornak (monasterio Almi ducis in honorem Sancte Margarete in Meches constructo) adta a meszesi kapun át szállított só adóját. Zsoldos Attila az apátság elhelyezkedéséből arra következtetett, hogy a dukátus területén lehetett, így Álmos azt a dukátus uraként, a 11. század legvégén alapíthatta ${ }^{81}$ Álmos az építkezést legkorábban 1096-ban kezdhette el - amikor a dukátus ura lett -, azonban kérdéses, hogy vajon elkészült-e a monostor. Zsoldos meggyőző érvelése szerint 1098 és 1101-1102 között vette el Kálmán Álmostól a hercegséget. ${ }^{82} \mathrm{E}$ szerint a hercegnek mindössze néhány - belharcokkal teli - év állt rendelkezésére a megépíttetésre, s ha ennyi idő alatt még fel is szentelték a kolostort, annak a dukátus uraként lehetett a kegyura. Ez a körülmény talán megmagyarázza, hogy Álmos a hercegségtől való megfosztása - s ezzel a bihari központja ${ }^{83}$ közelében lévő apátság elvesztése - után az új birtokai központjában (Dömösön $)^{84}$ miért kezdett bele mindjárt egy másik Szent Margit-egyház építésébe.

A Képes Krónika tanúsága szerint Álmos herceg 1107-1108 környékén jeruzsálemi zarándoklaton vett részt. E szövegrész után a krónika a dömösi pré-

78 Johannes de Thurocz, 421.

${ }^{79}$ Fejér, Georgius, Codex diplomaticus Hungariae ecclesiasticus ac civilis, Tomus II, Budae, 1829, 131; SöRös Pongrác, Az elenyészett bencés apátságok, A pannonhalmi Szent-Benedek-rend története XII/B, Bp., 1912, 449.

${ }^{80}$ RA 107. sz.; A zichi és vásonkeői gróf Zichy-család idősb ágának okmánytára, Codex diplomaticus domus senioris comitum Zichy de Zich et Vasonkeo, I-XII, szerk. Nagy Imre, Nagy Iván, Véghely Dezső, Barabás Samu, Krammerer Ernő, Dőry Ferenc, Lukcsics Pál, Pest-Bp., 18711931, I, 2.

${ }^{81}$ Zsoldos Attila, A dukátus felszámolásának kérdései (szerzői kézirat). Itt szeretném megköszönni Zsoldos Attilának, hogy a kéziratát a rendelkezésemre bocsátotta.

82 Zsoldos, Dukátus, i. m.

${ }_{83}$ Zsoldos Attila, Bihar megye korai története = Zsoldos Attila, Nagyvárad és Bihar a korai középkorban, Nagyvárad, Varadinum Kulturális Alapítvány, 2014, 182-190.

${ }^{84}$ Györffy György elmélete szerint a dukátus elvesztése után kárpótlásként birtokokat kapott Álmos. GYöRfFY György, A magyar állam megszilárdulása = Magyarország története tíz kötetben, I. Elözmények és magyar történet 1242-ig, főszerk. Székely György, Bp., Akadémiai Kiadó, 1984, 956. 
postság alapítását tárgyalja ${ }^{85}$ Makk Ferenc szerint a dömösi prépostság alapítása a zarándokút után, $1107-1108$ fordulóján történt ${ }^{86}$ A krónikás hagyomány szerint egyértelmüen a zarándoklat után szentelték fel az egyházat, ${ }^{87}$ Gerevich László azonban tévesen a keleti utazása elé helyezte az eseményt. ${ }^{88} \mathrm{Az}$ alapítás helyszíne azt sugallja, hogy a dukátus elvesztése után - talán az ezért kárpótlásként kapott birtoktesten - hozta létre a prépostságot a herceg. ${ }^{89}$ II. Béla 1138. évi okleveléből (amely 14. századi másolatban maradt fenn) is értesülünk a dömösi egyházról. Ebben az oklevélben a király megállapítja a dömösi egyház birtokállományát, mivel apja életében - szándéka ellenére - nem tudta rendezni azt. ${ }^{90}$ Az építtető tehát mindenképpen Álmos volt, s legalábbis a szentélyrész elkészült Kálmán király idején. A Képes Krónika elbeszélése szerint ugyanis Álmos és fia, Béla megvakíttatása után állítólag Kálmán király meg akarta öletni Álmost, aki a prépostság Szent Margit-oltárába kapaszkodott. ${ }^{91}$ A Képes Krónika nyomán az egyház felszentelése tehető az 1108. évre, ám épp ebből kiindulva az építkezési folyamatok korábban meg kellett kezdődjenek, a 12. század első éveiben. ${ }^{92}$ Nincs kizárva az sem, hogy bizonyos építkezési munkálatok II. Béla idejében is zajlottak, de müvészettörténeti szempontok alapján a 12. század első éveire datálható a faragványok zöme, s egyedülálló módon, észak-nyugat európai kapcsolatot feltételez. ${ }^{93}$

Végső soron, a fentebb elmondottak alapján az bizonyosnak vehető, hogy Álmos környezetébe tartozó bencések számára készült a Szent Margit-szakramentárium. Álmoshoz hü bencés ${ }^{94}$ lehetett akár a Szent Imre-legenda ${ }^{95}$ szerzője, aki saját bevallása szerint elkísérte Álmos herceget Konstantinápolyba ${ }^{96}$ Felvethető,

85 SRH I. 427, Csukovits Enikő, Középkori Magyar zarándokok, Bp. História-MTA Történettudományi Intézete, 2003, 24.

${ }^{86}$ MAKK Ferenc, A tizenkettedik század története, Bp., 2000 (Magyar Századok), 34-38.

87 SRH I. 427-428. - Magyar fordítás: ÍF 417.

88 Gerevich László, Dömös = Müemlékvédelem, 36(1992), $2,77$.

89 Zsoldos Attila, Dukátus.

90 RA I. 63. sz.

91 SRH I. 431-432. - Magyar fordítás: ÍF 420.

92 То́тн 2010. i. m. 64, Zsoldos, Dukátus i. m.

93 То́тн 2010. i. m. 64-65.

94 Bollók János, A Szent Imre-legenda, Pannonhalma és Ják, Egy királyi és egy magánkegyúri bencés monostor a középkorban = Mons Sacer, 996-1996, Pannonhalma 1000 éve, I-III szerk. Takács Imre, Pannonhalma, Pannonhalmi apátság, 1996, I, 341-355.

${ }^{95}$ A Szent Imre-legenda teljes kutatástörténetét jelen tanulmány keretei között lehetetlen áttekinteni. Mindazonáltal a medievisták a legendát a 12. század elejére vagy a 12. század derekára datálják. Erről összefoglalva 1. KLANICZAY 2000, i. m. 308-309. - A 12. század eleji datálás szerint a szerző Álmost az 1107. év körüli zarándoklatára kísérte el, míg a század közepi datálás szerint Álmos 1125-ös bizánci számüzetésében volt társa a bencés.

96 Scriptores rerum Hungaricarum tempore ducum requmque stirpis Arpadianae gestarum, I-II, szerk. Szentpétery, Emericus, Budapestini, 1937-1938. Reprint: Szerk. Szovák Kornél, Veszprémy László, Bp., 1999, 456. 
hogy Meszes volt a Szent Margit-szakramentáriumban említett bencés monostor, ám mivel ez nem készült el, végül Dömösön használták a kódexet. Mindemellett azonban a dömösi eredet sem zárható ki. Az Esztergomi benedikcionáléban szereplő egyház véleményünk szerint - Veszprémy László véleményét elfogadva - Dömös volt. Ezt bizonyítja az is, hogy Szent Margit kultuszának központja a 12. század eleji Magyarországon az adatok alapján csak Dömösön feltételezhető.

\section{A keleti és a nyugati hatás kérdése}

A kultusz eredetének kérdéséröl Orbán Imre tanulmányában és könyvében is azt hangsúlyozta, hogy nem volt szüksége sem Álmosnak, sem II. Andrásnak (aki Szent Margit fejereklyéjét vásárolta meg) a keleti hatásokra Szent Margit tiszteletének propagálásához, mert a nyugati hatásokban kell a kultusz erősödését keresni. ${ }^{97}$ Ez azonban nem ennyire egyértelmü, s a kultusz a keleti kereszténységtöl is kaphatott impulzusokat.

Szent Margit nyugati kultuszáról legújabban Juliana Dresvina publikált önálló monográfiát. Ebben ugyan föként a szent középkori angliai kultuszára koncentrál, ám elötte áttekinti a legendák szöveghagyományát és a szent korai nyugati kultuszát. ${ }^{98}$ Szent Margit életéről az egykorú források nem emlékeznek meg, csak az 5. században bukkan fel a neve, de ekkor korántsem biztos, hogy nem egy másik, Margitnak nevezett szentről van szó. Neve - mind Marina mind Margit formában - újra a 8. század végétől jelent meg mártirológiumokban, legendákban és patrocíniumként. ${ }^{99} \mathrm{~A}$ liturgikus források alapján kultusza a 8-11. század között leginkább a Köln és Tours környéki régiókra korlátozódott. ${ }^{100}$ Szent Margit ereklyéinek a translatiója is kérdéses. Valószínüleg a 8. században kerülhetett valamilyen ereklyéje Konstantinápolyba, ${ }^{101} \mathrm{~s}$ később a kultusz Szent Ménász templomában központosult. ${ }^{102} \mathrm{Az}$ egyik ereklyéje Itáliába kerülhetett 908 környékén, a Bolsena-tó melletti San Pietro della Valle egyházba, ami bizonyos mértékben fellendíthette a kultuszát. ${ }^{103}$ Azonban Szent Margit tisztelete - a többi vértanú szüzével egyetemben - csupán a 11. század második felétől élénkült meg NyugatEurópában, párhuzamosan más keleti szentek legendájának terjedésével. Ehhez annyiban hozzájárultak a keresztes hadjáratok, hogy az emberek nyitottabbak lettek a keleti történetek és a keleti szentek iránt. ${ }^{104}$ Mindez az egyház érdeké-

97 Orbán 2001, i. m. 105.

98 Dresvina 2016, i. m.

99 Uo. 13-14.

100 Uo. 20.

${ }_{101}$ Ross, M. C., Downey, G., A Reliquary of St Marina = Byzantinoslavica, 23(1962), 42.

102 AASS, Jul., V. 26, Dresvina 2016, i. m. 14.

103 Dresvina 2016, i. m. 43.

104 Erről részletesebben 1. Uhrin Dorottya, Szüzesség - szenvedés - szexualitás, A vértanú szüzek kultuszának elterjedése = Magister historiae II, Válogatott tanulmányok a 2014-ben és 2015-ban 
ben is állt, mivel népszerüsíteni igyekezett a keresztes hadjáratokat és embereket toborozni hozzá, amihez jó eszköz volt a vértanú szüzek kultuszának támogatása. A mártír szüzek legendáiban a gyengébbnek látszó keresztény legyőzi erős pogány ellenfelét, s mártírként Jézus mellett örök életet nyer. Ezek a történetek azt szimbolizálhatták, hogy a keresztes hadjáratok résztvevői miként viszonyuljanak az iszlám terjeszkedéséhez. ${ }^{105}$ A Margit-ereklyék translatiója is megindult 1145-ben, ${ }^{106}$ majd az egyik ereklye megszerzése épp a 4. keresztes hadjárat idején történt: Konrád, halberstadti püspök Konstantinápoly 1204-es elfoglalásakor jutott Margit egy ereklyéjéhez. ${ }^{107}$ Tehát a szakirodalomban Szent Margit nyugati kultuszának a megerősödését a keresztes hadjáratok (föként az első keresztes hadjárat, vagyis 1096-1099) utánra datálják. Ekkorra pedig - amennyiben a zágrábi püspökség alapításához kötnénk - a Szent Margit-szakramentárium nemcsak, hogy készen kellett volna lennie, de már el is kellett volna, hogy küldjék Zágrábba. Mivel a 11. század végi nyugati egyházban Szent Margit tiszteletének az elterjedéséhez hozzájárultak a keresztes hadjáratok, a középkori magyar Szent Margit tiszteletet is érhették keleti hatások. A magyar történeti kutatás úgy tartja, hogy Álmos herceg jeruzsálemi zarándoklata idején megfordult Konstantinápolyban is, ahol szerzett Szent Margit-ereklyéket. ${ }^{108}$ Erre azonban nincsen se írásos, se tárgyi bizonyítékunk, Bizáncból szerezhetett ereklyéket a herceg, amelyek mára elvesztek.

Noha Álmos herceg nyerhetett impulzusokat a nyugati kereszténységből is Margit kultuszának propagálására - hiszen a Német-Római Birodalommal intenzív kapcsolatokat ápolt (Köln környékén pedig kimutatható Margit kultusza) - ám mégsem vethető el a keleti hatás. Erre utal az is, hogy Álmos egyházalapításai után épp a bizánci neveltetésủ III. Béla idején erősödik meg a kultusz. Béla

megrendezett középkorral foglalkozó, mesterszakos hallgatói konferenciák előadásaiból, szerk. Farkas Csaba, Lados Tamás, Ribi András, Uhrin Dorottya, Bp., ELTE BTK Történelemtudományok Doktori Iskola, 2016, 158-178.

105 Sands, Tracey R., The Company She Keeps. The Medieval Swedish Cult of Saint Katherine of Alexandria and its Transformations, Tempe, 2010 (Medieval and Renaissance Texts and Studies, 362), $1,19$.

106 1145-ben Margit a Bolsena-tó közelében lévő San Pietro della Valle egyházban lévő ereklyéjét átszállították Montefiasconeba. AASS Jul., V., 28, 44.

107 Bartlett, Robert, Why Can the Dead Do Such Great Things? Saint and Worshippers from the Martyrs to the Reformation, Princeton, Oxford, Princeton University Press, 2011, 310; DresvinA 2016, i. m. 14.

${ }^{108}$ GYÖRfFY György, A magyar állam megszilárdulása = Magyarország története, Elözmények és magyar történet 1242-ig, föszerk. Székely György, Bp., 1984 (Magyarország története, I/1-2), 956-958; BENKö Elek, A dömösi prépostság régészeti kutatása = Paloták, kolostorok, falvak, Gerevich László (1911-1997) középkori kutatásai, Kiállítási katalógus, szerk. Benda Judit, Benkő Elek, Magyar Károly, Bp., 2011, 69-70; Johannes de Thurocz, Chronica Hungarorum. II. Commentarii. 1. Ab initiis usque ad annum 1301. Comp. Elemér Mályusz adiuv. Julio Kristó, Bp., 1988, (Bibliotheca Scriptorum Medii Recentisque Aevorum, VIII), 420-421. 
az egyik leányát is Margitnak nevezte, ${ }^{109}$ bár ebben szerepe lehetett antiochiai származású feleségének, csakúgy, mint a kultusz támogatásában. A meszesi és a dömösi egyházon kívül a 12. században csak Karcsán van biztos adatunk Szent Margit patrocíniumra. A templomot feltehetőleg III. Béla idején alapították a stefaniták. ${ }^{110}$ A lovagrendi eredet miatt legalábbis a keresztes eszmével kapcsolatban van ez az egyház. Visszatérve a kultusz megjelenésére, Álmos herceg horvát királyként is kapcsolatba kerülhetett a bizánci kereszténységgel. Tehát azt nem lehet megállapítani, hogy Álmos herceg keleten vagy nyugaton találkozott-e Szent Margit kultuszával, s miért ennek a szentnek a kultuszát mozdította elö, de annyi bizonyosnak tekinthető, hogy ő honosította meg a kultuszát.

\section{Kálmán a sárkány?}

Kristó Gyula szerint a dömösi egyház alapítása Álmos részéről kihívás volt Kálmán felé. ${ }^{111}$ Ezt továbbgondolva Orbán Imre arra a következtetésre jutott, hogy a sárkány és a fekete ember/démon képében megjelenő ördögöt legyőző Margit az alkalmatlan uralkodóval (Kálmán) szembeni küzdelmet szimbolizálja. ${ }^{12}$ Ezt az elképzelést Koszta László is átvette, ${ }^{113}$ szerinte a dukátus megszünése után Álmos a Nyitráról távozó papságnak alapított Dömösön egyházat, ezzel átmentve a hercegi vagyont. ${ }^{114}$ Koszta ötletével a továbbiakban nem kívánok foglalkozni. ${ }^{115}$ Viszont szeretném megvizsgálni, hogy lehetséges-e a „történet” alapjául szolgáló sárkány - Kálmán király megfeleltetés.

Orbán Imre hipotézise onnan eredhet, hogy kiindulási alapként tette meg azt a krónikarészletet, amely szerint Kálmán „Külsejét tekintve jelentéktelen volt, de ravasz és tanulékony, borzas, szőrös, félszemü, púpos, sánta és dadogó". ${ }^{116}$ Erről a krónikarészletről azonban a kutatás bebizonyította, hogy az Álmos-ági krónikás

109 Vö. 7. lj.

${ }^{110}$ SzAKÁCs Béla Zsolt, A lovagrendek müvészete a középkori Magyarországon = Magyarország és a keresztes háborúk, Lovagrendek és emlékeik, szerk. Laszlovszky József, Majorossy Judit, Zsengellér József, Máriabesenyő, Gödöllő, 2006. 242.

111 KRIsTó Gyula, A XI. századi hercegség története Magyarországon, Bp., Akadémiai Kiadó, 1974, 120.

112 Orbán 1997, i. m. 42-50; Orbán 2001, i. m. 108-110.

113 Koszta László, Adalékok Antiochiai Szent Margit tiszteletéhez = Acta Universitatis Szegediensis. Acta Historica, 126(2006), 23-28.

114 KoszTa László, Egyház és intézményei a középkori Pest és Pilis megyében = Pest megye monográfiája I/2, A honfoglalástól 1686-ig, szerk. Zsoldos Attila, Bp., Magyar Nemzeti Levéltár Pest Megyei Levéltára, 2001, 203; KoszTA László, A nyitrai püspökség létrejötte, Nyitra egyháztörténete a 9-13. században = Századok, 143(2009), 298-299.

115 Koszta László elképzelését vö. ThoroczKay 2012, i. m. 414. és Zsoldos, Dukátus, i. m.

116 SRH I. 421. - Magyar fordítás: ÍF 413. 
Kálmán lejáratása céljából írta. ${ }^{117}$ Még abban az esetben is, ha volt valamilyen testi hibája Kálmánnak, ez nem befolyásolhatta az uralkodásban, hiszen a Képes Krónika szerint például személyesen részt vett a háborúiban. ${ }^{118}$

Orbán Imre ezen ötletének további alátámasztására legendákat hozott fel példaként. Ám az idézett cikkben egy jelentős módszertani probléma is akad: ezek a legendák - amelyek segítségével megpróbál rekonstruálni egy 12. század eleji eseményt - fóként a 15-16. századból származnak. Még legkorábbi idézett példája is a 13. századi harmadrendi domonkos nővér esete. ${ }^{119} \mathrm{Ez}$ azért is jelentős probléma, mivel a szentkultusz jelentős változásokon ment át a 11-16. század között, ${ }^{120} \mathrm{~s}$ a szentek legendái is több alkalommal bővültek. ${ }^{121}$ És akkor még nem is beszélünk arról az óriási változásról, ami a 12. században a női vallásosság, női szentek tisztelete terén végbement. Természetesen - jóllehet már könyvtárnyi irodalom született a szentkultusz középkori változásairól $-{ }^{122}$ mindezt nem lehet részletesen bemutatni egy tanulmány keretein belül. Viszont egy dologra mindenképpen fel kell hívni a figyelmet: bár Szent Margit legendájának leghíresebb jelente a sárkánnyal való küzdelme és leggyakrabban ábrázolt attribútuma a sárkány, a legenda maga mégsem a vele való harc köré összpontosul. Szent Margit fô ellenfele a legendájában Olibrius, a pogány nemesi származású prefektus, aki meg akarja szerezni magának a szüzet. A vértanú szüzek legendáiban közös vonás, hogy a leendő szenteknek az uralkodó, a prefektus vagy a bíró miatt kell el-

117 KRIsTó Gyula, Magyar historiográfia I. Történetírás a középkori Magyarországon, Bp., Osiris, 2002, 39-40.

118 Így például az országba betörő keresztesek ellen, személyesen ment Oroszországba, a kunok ellen, miután Álmos elfoglalta Újvárat személyesen vett részt az ostromban. Lásd SRH I. 422-427. - Magyar fordítás: ÍF 414-417.

119 Orbán 1997, i. m. 44.

${ }^{120}$ A vértanú szüzek kultuszának változásáról 1. WINSTEAD, Karen A., Changing patterns of conflict in Middle English virgin martyr legends = Medieval Perspectives, 1989-1990, 4-5, 229-238.

121 A középkori legendák bővüléséről Szent Katalin legendájának a példáján 1. BEATIE, Bruce A., Saint Katherine of Alexandria, Traditional Themes and the Development of a Medieval German Hagiographic Narrative $=$ Speculum, 52(1977), 785-800.

${ }^{122}$ A téma népszerűsége miatt jelentős mennyiségü szakirodalommal rendelkezik, csak néhányat sorolnék fel. Vauchez, André, Saints admirables et saints imitables: les fonctions de l'hagiographie ont-elles changé aux derniers siècles du Moyen Âge?" = Les fonctions des saints dans le monde occidental (IIIe-XIIIe siècle) Actes du colloque de Rome (27-29 octobre 1988) Rome, École Française de Rome, 1991, 161-172; Images of Sainthood in Medieval Europe, szerk. BlumenfeldKosinski, Renate, Szell Timea, Ithaca, 1991; Schulemburg, Jane Tibbets, Sexism and the celestical gynaeceum - from 500 to 1200 = Journal of Medieval History, 4(1978), 117-133; VAUCHEZ, André, Sainthood in the Later Middle Ages, Cambridge, 1997, 268-269; Medieval Women, szerk. Baker, Derek Oxford, 1978 (Studies in Church History); Bynum, Caroline Walker, Holy Feast and Holy Fast, The Religious Significance of Food to Medieval Women, Berkely, Los Angeles, London, University of California Press, 1987; KLAniczay 2000, i. m.; Goodich, Michael, Vita perfecta: The Ideal of Sainthood in the Thirteenth Century, Stuttgart, Anton Hiersemann, 1982 (Monographien zur Geschichte des Mittelalters, 25); Weinstein, Donald, Bell, Rudolph M., Saints and society: the two worlds of western Christendom, 1000-1700, Chicago, University of Chicago Press, 1982. 
szenvedniük a megpróbáltatásokat, ${ }^{123}$ illetve az, hogy a legendák a kereszténység és a pogányság közötti konfliktus köré összpontosulnak. ${ }^{124}$ A pogány előkelök azok, akik a szentekkel szemben állnak, $\mathrm{s}$ a szentek szenvedései közben mindenféle csodás dolog történik, például Margit esetében az, hogy megküzd a sárkánynyal. Tehát még ha Kálmán király kihívásként is értelmezte a dömösi prépostság alapítását és patrocínium választását, inkább azonosíthatta magát Olibriusszal, mint a sárkánnyal. Azonban az sem hihető, hogy az eredetileg klerikusnak szánt Kálmánt egy pogány előkelőhöz hasonlította volna bárki.

\section{Összegzés}

Az eddig leírtakból kitünik, hogy forrásokkal nem bizonyítható Antiochiai Szent Margit 11. századi tisztelete Magyarországon, csak a század utolsó éveiben. A szent neve talán ismert lehetett a klerikusok, közülük is föként a külföldiek számára, de Szent Margit kultusza Magyarországon ténylegesen Álmos herceg egyházalapításaival kezdődött.

Ennek alapján az ún. Hahóti kódex, vagyis a Szent Margit-szakramentárium rendeltetési helye talán Meszes, de valószínübb, hogy Dömös lehetett. Vélhetően Szent Margit kultuszközpontja a 12. században Dömös volt, köszönhetően a kultusz hercegi támogatásának, hisz maga Álmos is egy ideig ott élt. A motivációt Szent Margit védőszentté emelése mögött nem ismerjük, de nem valószínü, hogy kihívásként értelmezte az uralkodó a patrocínium választást.

Álmos herceg egyházalapításai kapcsán a tanulmány bemutatja, hogy nem egyértelmü a kultusz nyugati eredete, mivel Szent Margit kultusza a 11. század második felében Nyugat-Európában éppen csak megerősödésben volt, korántsem egy meggyökerezett, erős tiszteletről volt szó. Mindez csak a 12-13. századtól jött el, vagyis az érett középkortól kezdve a nyugati hatás a Szent Margit kultuszára kétségtelen. A magyar kereszténység pogánylázadásokkal tarkított első évszázadában kevés esélye volt annak, hogy ereklye nélkül meghonosodjon egy kevésbé ismert, keleti eredetű szent tisztelete. Szent Ányosnak I. András idejétől, Szent Kálmánnak pedig Péter király idejétől volt ereklyéje az országban - Kálmán ráadásul a közelben szenvedett vértanúhalált -, mégsem lett igazán jelentős kultuszuk az országban. ${ }^{125}$

${ }^{123}$ Winstead, Karen A., Virgin Martyrs, Legends of Sainthood in Late Medieval England, Ithaca, 1997, 1-18.

124 Winstead 1989-1990, i. m. 229.

${ }^{125}$ Kerny Terézia, Szent Kálmán és Könyves Kálmán kultuszáról = Ars Hungarica, 29(2001), 1, 9-32; Csákó Judit, Szent Ányos püspök franciaországi és magyarországi kultuszáról = Magyar Egyháztörténeti Vázlatok 24(2012), 3-4, 13-22. 


\title{
UHRIN, DOROTTYA
}

\section{Hungary's Earliest Cult of Saint Margaret of Antioch}

\author{
The Church Foundations of Duke Álmos \\ and the Saint Margaret Sacramentary
}

The present study focuses on the appearance of the cult of Saint Margaret of Antioch in medieval Hungary. Duke Álmos, the brother of King Coloman (1095-1116), founded a monastery at Meszes and a collegiate chapter at Dömös in honour of the saint. Earlier literature has argued that the cult of Saint Margaret already existed in the eleventh century, and used this to explain the church foundations of Duke Álmos, even though analysis of the sources revealed that the veneration of Saint Margaret cannot be proved before the very end of the eleventh century. The name of the saint might have been known to clerics earlier, but the first trace of her veneration in Hungary is the foundations of Duke Álmos. The monastery of Meszes likely was located in his duchy, and thus Álmos must have founded it before King Coloman stripped him of his duchy. This means that he most likely founded it at the very end of the eleventh century. Then Álmos founded a collegiate chapter dedicated to St Margaret in Dömös, the centre of his new territory. The chapter was consecrated in 1108 , and thus construction started in the first years of the twelfth century. Imre Orbán argued that Álmos chose Saint Margaret as patron saint because the legend of the saint (i.e. Margaret defeating the dragon) symbolized his struggle against the incompetent ruler (Coloman). This idea might have been inspired from the Chronicon Pictum, which describes Coloman as malformed, though that part of the chronicle is not reliable. Moreover, the legend of Margaret centres upon the confrontation of Christianity with Paganism, rather than her fight with the dragon. While exploring those topics, the present study sheds light on the provenience and the dating of the Saint Margaret Sacramentary, the earliest liturgical book of Hungary. The codex was certainly made for a Benedictine monastery which was dedicated to Margaret. The Hungarian dynastic saints' cults stand out in the codex which might connect it to the royal family. Consequently, the Sacrament perhaps was made for the Benedictines of Meszes, but eventually was used in the chapter of Dömös.

Keywords: Saint Margaret of Antioch, Duke Álmos, liturgy, cult of saints, Saint Margaret Sacrament, $11-12^{\text {th }}$ centuries 